\title{
The Effect of Sport Activities on Self-Confidence Levels of 13-14 Year-Olds
}

\author{
Salih Tutku Yaylacı \\ Samsun Provincial Directorate of Youth and Sports \\ Esenevler Mahallesi Atatürk Bulvarı No. 123, 55200 Atakum, Samsun, Turkey \\ Tel: 90-546-417-1692Ｅ-mail: tutkuyaylaci@gmail.com
}

Çisem Ünlü (Corresponding author)

Faculty of Sport Sciences, Hitit University

Spor Bilimleri Fakültesi Kuzey Kampüsü Çevre Yolu Bulvarı 19030 Çorum, Turkey

Tel: 90-530-884-3725Ｅ-mail: cisemunlu@hotmail.com

Received: November 5, 2021 Accepted: December 2, 2021

Published: December 31, 2021

doi:10.5296/jei.v7i3.19216 URL: https://doi.org/10.5296/jei.v7i3.19216

\begin{abstract}
This study is conducted to determine the effect of the sport activities on the self-confidence levels of 13-14 year-olds. Self-confidence formation starts especially at ages of 13-14 and affects the success of the individuals. Therefore, whether sport activities have any effects on self-confidence and whether the demographic characteristics affect self-confidence are analyzed in our study. Total of 272 individuals, 159 individuals participating in sport activities and 113 individuals not participating in sport activities at Ilkadım, Carsamba and Bafra Youth Centers providing services under the scope of the sport activities by the Samsun Youth and Sports Provincial Directorate in the season of 2018-2019 have participated voluntarily in this study. In this research, survey method among the methods used in applied research is preferred. As the data collection tool, a survey form consisting of two sections is used. In the first section the 'Personal Information Form' prepared by the researcher is used. In the personal information form, demographic information as father's employment status, mother's employment status, mother and father's marital status, number of siblings and familial income status are included. In the second section, the 'Self-confidence scale' developed by Akın (2007) is used. Acquired data is tested at 95\% confidence level with the
\end{abstract}


aid of SPSS program and the significance level is determined as 0.05 . In the light of the date in the study, before the statistical analysis was begun, normality assumption and homogeneity tests are applied, as the result of the Kolmogorov-Smirnov and Levene tests conducted it is determined that the data has normal distribution $(\mathrm{p}>0.05)$. As the data shows normal distribution, it is decided to conduct parametric analysis. In comparison of the groups, independent sample t-test and one way ANOVA analyses are used. According to the acquired data and the analyses conducted, as the result of comparison of the Internal and External Self-confidence scores of the individuals participating in the sport activities according to the father's employment status, mother's employment status, mother and father's marital status, number of siblings and familial income status, it is concluded that there is no significant differences. Whereas in the gender variable, while there is no significant difference in the Internal Self-confidence sub dimension, in the External Self-confidence sub dimension it is found out that the males have significantly higher scores compared to the females. Also it is seen that the self-confidence levels of individuals participating in sport activities are statistically higher than the ones who do not participate in the sport activities $(\mathrm{p}<0.05)$.

Keywords: Sports, Activity, Self-confidence, Age.

\section{Introduction}

Sports provides for the person to resist against the negativities and dangers from outside via knowing and understanding oneself, and to create an environment away from depression and stress present in one's life. Through the dynamism it grants to the person, it ensures that one may enjoy the life in health and look at life in a positive way. It supports the character development in psychological and spiritual aspects (Gökhan \& Olgun, 1979).

Burton and Platts (2010) define confidence as to act properly and effectively in any situation. There are many definitions for self-confidence in the literature. It is the feelings and thoughts of the individual regarding that one is in peace with one's self and identifies with one's self via trusting one's skills, decisions and strength, and it is the ability of one in being successful or the purest state of the skills present in the person (Mahoney \& Chapman, 2004). In other words, self-confidence can be stated as the individuals thinking and believing that they might realize the behavior expected and requested from them (Weinberg \& Gould, 2003). When individuals do not feel themselves valuable regarding self-confidence, they become unable to meet their basic needs and live in distress. Individuals shape and add value to the identities they acquired. The self-confidence concept is known to be a process progressing from childhood to present. It is known to be process progressing from childhood and if support is provided for it improvement, individuals may self-express themselves in almost all matters throughout their lives. While they grow as individuals with high communication skills against their environment, who are social and confident, they shall be in positive thoughts during this process (Basoğlu, 2007). Individuals with low self-confidence think that they cannot solve the daily life problems, continuously experience the stress of despair and the anxiety of the conditions they are in. They are affected quickly and live a life dependent on their environment (Kurtuldu, 2007).

It is possible to divide self-confidence into two as internal and external. Internal 
Self-confidence consists of the self-reflection, self-relations of the individuals, in a more general sense, it is formed as the result of the communication of the individuals with themselves within their internal world. Whereas, External Self-confidence determined the tendencies of the individuals in their external world, their communication with their environment, their qualities of self-expression against others and of self-control over their emotions (Humphreys, 2002). Internal confidence and external confidence together is for the individuals to think positively against life, to acquire the self that may deal with the problems in life in line with the goals they establish for themselves, and as the result of this achievement, to have the chance to know themselves better and to love theirself and character (Basoğlu, 2007). There are many factors affecting the formation of self-confidence. These factors can be listed as family, parental approach, academic success, self-evaluation of the individual, divorce, environmental effects, responsibility, intelligence, discipline methods and other factors. In sports, whereas, self-confidence can generally be associated as interconnected with success. Researchers have stated that the self-confident athletes feel that they shall be much more successful in their efforts, think that they have the physical, emotional, mental etc. abilities to realize their potentials and what they have that is required for success, and feel this existing ability (Y1ldırım, 2013; Ceylan et al., 2020). It is established with research that sports positively affect both the physical and spiritual health. It is know that there are various changes in the body and hormones occurring with sports. One of these changes, as known, is happiness. It is know that through individual happiness the feeling of high self-confidence and of success emerge. Highly self-confident athletes are more hardworking, productive, successful in overcoming hardships and achieving set goals, and have higher motivation compared to the athletes with low self-confidence. In addition, self-confidence has effects on being acumen and highly concentrated (Vealey, 2009).

\section{Method}

\subsection{The Study Group}

The population of the research is the individuals at the ages of 13-14 that participate in sport activities and individuals at the same ages that never participated in the sport activities at Youth Centers providing service under the organization of the Samsun Youth and Sports Provincial Directorate. When determining sample size in the study, the sample volume is calculated using Strength Analysis, as the result of the formula, the sample number determined for $99 \%$ confidence level and 5\% error margin is achieved as 159 individuals participating in sport activities and 113 individuals never participated in these sport activities at the Youth Centers connected to the Youth and Sports Provincial Directorates.

\subsection{Data Collection Tools}

In the study, the data collection tool is composed of two sections. In the first section the 'Personal Information Form' prepared by the researcher is used. In the personal information form, demographic information as father's employment status, mother's employment status, mother and father's marital status, number of siblings and familial income status are included. In the second section, the 'Self-confidence scale' developed by Akın (2007) is used. The total number of items in the self-confidence scale is 33 . Therefore, the highest score to be taken 


\section{Macrothink}

from this scale that is prepared in Likert type with 5 degrees is 165 and the lowest score is 33 . Higher points taken from the scale that contains no negative items shows higher level of self-confidence.

\subsection{Ethical Aspect of the Research}

In order for the assessment of the research regarding its ethical conformity, the Hitit University Non-Invasive Clinical Research Ethical Board is applied to and the board has ethically cleared the research to be conducted. The permissions are acquired from Samsun Youth Services Provincial Directorate in order to apply survey forms to the individuals included in the research. The participants of the study are asked for signed Guardian/Parent Consent Form; the necessary explanations are given to the individuals performing sport activities and to the one that have never participated to these activities and it is ensured that they are participating willingly.

\subsection{Data Analysis}

In the light of the date in the study, before the statistical analysis was begun, normality assumption and homogeneity tests are applied, as the result of the Kolmogorov-Smirnov and Levene tests conducted it is determined that the data has normal distribution $(p>0.05)$. As the data shows normal distribution, it is decided to conduct parametric analysis. In comparison of the groups, independent sample t-test and one way ANOVA analyses are used. The findings achieved are stated in means and standard deviations. 


\section{Results}

Table 1. Demographic characteristics of individuals participating in sport activities and not participating in sport activities

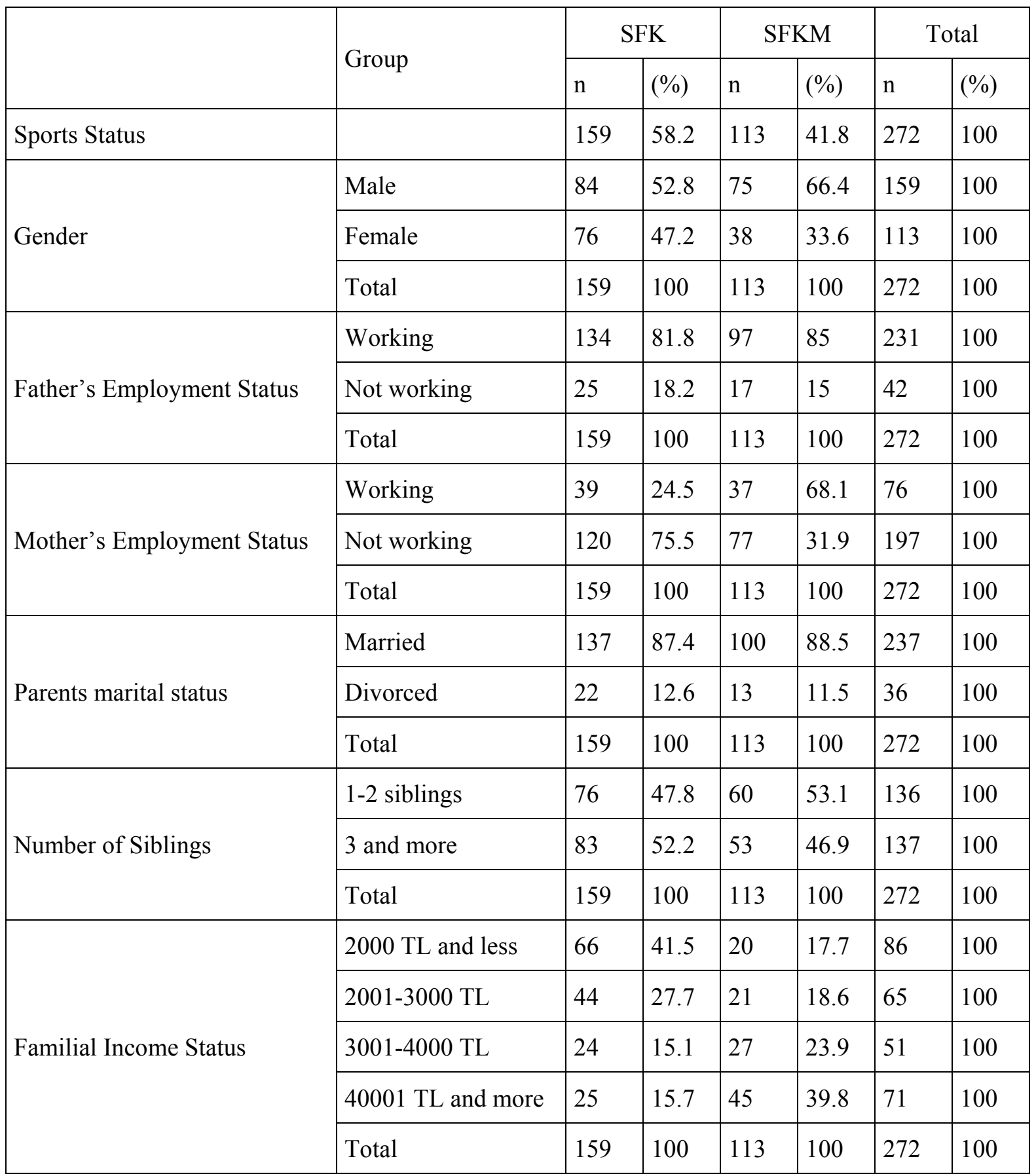

The participant group is composed of 58.2\% individuals participating in sport activities and $41.8 \%$ individuals not participating in sport activities. When compared according to the gender $52.8 \%$ of the individuals participating in sport activities are male and $47.2 \%$ of the 


\section{Macrothink

same is female. Whereas, $66.4 \%$ of non-participating ones is male and $33.6 \%$ of the same is female. When father employment status is examined, $81.8 \%$ of the fathers of individuals participating in sport activities are in working status and $18.2 \%$ of them are not working. Whereas for the individuals not participating in sport activities, the percentage of the working fathers is determined as $85 \%$ and the same of not working fathers as $15 \%$. Again according to the responds given by the participants, the working mother percentage for the individuals participating in sport activities $24.5 \%$ and not working ones are $75.5 \%$. For the mothers of the individuals not participating in sport activities, not working status is found as $31.9 \%$ and working status as $68.1 \%$.

Based on the marital status, when looked at the individuals participating in sport activities, the ratio of the ones living in families where parents are married is $87.4 \%$ and ratio for the divorced parents is $12.6 \%$. Whereas, for the individuals not participating in sport activities, the divorced parents ratio is $11.5 \%$ and married parents ratio is $88.5 \%$. When the responds of the participants on the number of siblings, $47.8 \%$ of the participants active in sports have $1-2$ siblings and $52.2 \%$ of the same have 3 and more siblings; whereas for the individuals not participating in sport activities $53.1 \%$ of them have 1-2 siblings and $46.9 \%$ have 3 and more siblings. When the familial income levels of the participants is examined, for the individuals participating in sport activities $41.5 \%$ has 2000 TL and less, $27.7 \%$ has $2001-3000$ TL, 15,1\% has 3001-4000 TL, and 15.7\% has $4001 \mathrm{TL}$ and more income. For the individuals not participating in sport activities, $17.7 \%$ has $2000 \mathrm{TL}$ and less, 18.6\% has 2001-3000 TL, $23.9 \%$ has $3001-4000 \mathrm{TL}$, and $39.8 \%$ has $4001 \mathrm{TL}$ and more income (Table 1). 
Table 2. For individuals participating in sport activities, according to the demographic information, comparison of Internal Self-confidence and External Self-confidence scores

\begin{tabular}{|c|c|c|c|c|c|c|c|}
\hline & & & $\mathrm{n}$ & Ort. & S.S. & $\mathrm{t}$ & $\mathrm{p}$ \\
\hline \multirow{4}{*}{ Gender } & \multirow{2}{*}{ Internal Self-confidence } & Female & 76 & 66.6 & 11.11 & \multirow{2}{*}{-1.984} & \multirow{2}{*}{0.049} \\
\hline & & Male & 84 & 70.49 & 11.22 & & \\
\hline & \multirow{2}{*}{ External Self-confidence } & Female & 76 & 63.5 & 10.39 & \multirow{2}{*}{-2.612} & \multirow{2}{*}{$0.01 *$} \\
\hline & & Male & 84 & 68.2 & 9.78 & & \\
\hline \multirow{4}{*}{ Father's Employment Status } & \multirow{2}{*}{ Internal Self-confidence } & Working & 134 & 67.36 & 11.28 & \multirow{2}{*}{-0.882} & \multirow{2}{*}{0.379} \\
\hline & & Not Working & 25 & 69.52 & 11.09 & & \\
\hline & \multirow{2}{*}{ External Self-confidence } & Working & 134 & 64.57 & 10.49 & \multirow{2}{*}{-0.716} & \multirow{2}{*}{0.475} \\
\hline & & Not Working & 25 & 66.2 & 10.06 & & \\
\hline \multirow{4}{*}{ Mother's Employment Status } & \multirow{2}{*}{ Internal Self-confidence } & Working & 39 & 67.72 & 9.85 & \multirow{2}{*}{0.013} & \multirow{2}{*}{0.99} \\
\hline & & Not Working & 120 & 67.69 & 11.7 & & \\
\hline & \multirow{2}{*}{ External Self-confidence } & Working & 39 & 65.67 & 8.92 & \multirow{2}{*}{0.576} & \multirow{2}{*}{0.565} \\
\hline & & Not Working & 120 & 64.56 & 10.87 & & \\
\hline \multirow{4}{*}{ Parents marital status } & \multirow{2}{*}{ Internal Self-confidence } & Married & 137 & 68.15 & 10.69 & \multirow[b]{2}{*}{1.255} & \multirow{2}{*}{0.211} \\
\hline & & Divorced & 22 & 64.91 & 14.24 & & \\
\hline & \multirow{2}{*}{ External Self-confidence } & Married & 137 & 65.18 & 10.13 & \multirow{2}{*}{1.043} & \multirow{2}{*}{0.298} \\
\hline & & Divorced & 22 & 62.68 & 12.03 & & \\
\hline \multirow{4}{*}{ Number of Siblings } & \multirow{2}{*}{ Internal Self-confidence } & 1-2 siblings & 76 & 68.34 & 11.97 & \multirow{2}{*}{0.69} & \\
\hline & & 3 siblings and more & 83 & 67.11 & 10.58 & & 0.491 \\
\hline & & 1-2 siblings & 76 & 65.46 & 10.84 & & \\
\hline & External Selt-contidence & 3 and more & 83 & 64.25 & 10.02 & 0.13 & $0.46 /$ \\
\hline & & 2000 and less & 66 & 66.32 & 11.35 & & \\
\hline & & 2001-3000 & 44 & 69 & 10.94 & & \\
\hline & Imternal sent-contraence & $3001-4000$ & 24 & 67.92 & 11.29 & 0.551 & 0.044 \\
\hline & & 4001 and more & 25 & 68.4 & 11.73 & & \\
\hline 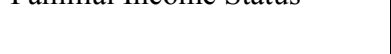 & & $2000 \mathrm{TL}$ and less & 66 & 64.53 & 10.06 & & \\
\hline & & 2001-3000 TL & 44 & 65.77 & 11.1 & & \\
\hline & External Self-confidence & $3001-4000 \mathrm{TL}$ & 24 & 64.83 & 10.12 & 0.194 & 0.901 \\
\hline & & 4001 TL and more & 25 & 63.96 & 10.85 & & \\
\hline
\end{tabular}

Note. ${ }^{*} \mathrm{p}<0.05$. 


\section{Macrothink}

As the result of comparison of the Internal and External Self-confidence scores according to the father's employment status, mother's employment status, mother and father's marital status, number of siblings and familial income status of the individuals participating in sport activities, it is found out that there are no significant differences. Whereas in gender variable while no significant difference is found in Internal Self-confidence sub dimension, in External Self-confidence sub dimension it is found out that males have significantly higher scores compared to females $(\mathrm{p}<0.05)$ (Table 2$)$.

Table 3. Comparison of the Internal Self-confidence and External Self-confidence scores of the individuals participating in sport activities and the individuals not participating in sport activities

\begin{tabular}{|l|l|l|l|l|l|l|}
\hline \multicolumn{2}{|c|}{} & n & Ort. & S.S. & t & p \\
\hline \multirow{3}{*}{ Internal Self-confidence } & SFK & 159 & 67.70 & 11.25 & \multirow{2}{*}{2.725} & \multirow{2}{*}{0.007} \\
\cline { 2 - 7 } & SFKM & 114 & 64.02 & 10.66 & & \\
\hline \multirow{3}{*}{ External Self-confidence } & SFK & 159 & 64.83 & 10.41 & \multirow{2}{*}{3.091} & \multirow{2}{*}{$\mathbf{0 . 0 0 2 *}$} \\
\cline { 2 - 6 } & SFKM & 114 & 60.80 & 10.93 & & \\
\hline
\end{tabular}

Note. $* \mathrm{p}<0.05$.

The mean of the scores obtained by the individuals participating in sport activities at the self-confidence scale Internal Self-confidence sub dimension is 67.70, and mean of the scores obtained by the individuals not participating in sport activities at the self-confidence scale Internal Self-confidence sub dimension is 64.02. At the youth center for the individuals participating in sport activities, the mean of the scores for the self-confidence scale External Self-confidence is 64.83 , for the individuals not participating in sport activities, the mean of the scores for the self-confidence scale External Self-confidence is 60.80. When the scores of these groups are compared, at Internal and External Self-confidence values, the scores of the individuals participating in sport activities are found higher than the individuals not participating in sport activities. In addition, it is observed that the individuals participating in sport activities and the individuals not participating in sport activities are differentiating significantly at the External Self-confidence sub dimension $(p<0.05)$ (Table 3 ). 


\section{Macrothink}

Table 4. For individuals participating in sport activities, according to the gender variable, comparison of Internal Self-confidence and External Self-confidence scores

\begin{tabular}{|c|c|c|c|c|c|c|c|}
\hline \multicolumn{3}{|l|}{ Gender } & $\mathrm{n}$ & Ort. & S.S. & $\mathrm{t}$ & $\mathrm{p}$ \\
\hline \multirow{4}{*}{ Female } & \multirow{2}{*}{ External Self-confidence } & SFK & 76 & 64.83 & 10.27 & \multirow{2}{*}{7.064} & \multirow{2}{*}{$<0.001 *$} \\
\hline & & SFKM & 38 & 50.50 & 10.08 & & \\
\hline & \multirow{2}{*}{ Internal Self-confidence } & SFK & 76 & 67.63 & 11.24 & \multirow{2}{*}{4.543} & \multirow{2}{*}{$<0.001 *$} \\
\hline & & SFKM & 38 & 57.61 & 10.84 & & \\
\hline \multirow{4}{*}{ Male } & \multirow{2}{*}{ External Self-confidence } & SFK & 84 & 64.85 & 10.53 & \multirow{2}{*}{6.332} & \multirow{2}{*}{$<0.001 *$} \\
\hline & & SFKM & 75 & 55.07 & 8.73 & & \\
\hline & \multirow{2}{*}{ Internal Self-confidence } & SFK & 84 & 67.80 & 11.28 & \multirow{2}{*}{3.733} & \multirow{2}{*}{$<0.001 *$} \\
\hline & & SFKM & 75 & 61.64 & 9.27 & & \\
\hline
\end{tabular}

Note. ${ }^{*} \mathrm{p}<0.05$

The mean of the scores obtained by the male students participating in sport activities at the self-confidence scale Internal Self-confidence sub dimension is 67.80, and mean of the scores obtained by the male students not participating in sport activities at the self-confidence scale Internal Self-confidence sub dimension is 61.64. The mean of the scores obtained by the female students participating in sport activities at the self-confidence scale Internal Self-confidence sub dimension is 67.63 , and mean of the scores obtained by the female students not participating in sport activities at the self-confidence scale Internal Self-confidence sub dimension is 57.61. When the scores between these groups are compared, it is concluded that Internal and External Self-confidence scores of both men and women participated in the sport activities have differentiated significantly compared to the individuals not participating in the sport activities $(\mathrm{p}<0.05)($ Table 4$)$. 
Table 5. According to the employment status of the father, comparison of the Internal Self-confidence and External Self-confidence scores of the individuals participating in sport activities and the individuals not participating in sport activities

\begin{tabular}{|c|c|c|c|c|c|c|c|}
\hline & & & $\mathrm{n}$ & Ort. & S.S. & $\mathrm{t}$ & $\mathrm{p}$ \\
\hline \multirow{4}{*}{ Working } & \multirow{2}{*}{ Internal Self-confidence } & SFK & 134 & 67.36 & 11.28 & \multirow{2}{*}{2.507} & \multirow{2}{*}{$0.013 *$} \\
\hline & & SFKM & 97 & 63.65 & 10.83 & & \\
\hline & \multirow{2}{*}{ External Self-confidence } & SFK & 134 & 64.57 & 10.49 & \multirow{2}{*}{2.656} & \multirow{2}{*}{$0.008 *$} \\
\hline & & SFKM & 97 & 60.74 & 11.27 & & \\
\hline \multirow{4}{*}{ Not Working } & \multirow{2}{*}{ Internal Self-confidence } & SFK & 25 & 69.52 & 11.09 & \multirow{2}{*}{1.029} & \multirow{2}{*}{0.31} \\
\hline & & SFKM & 17 & 66.12 & 9.59 & & \\
\hline & \multirow{2}{*}{ External Self-confidence } & SFK & 25 & 66.2 & 10.06 & \multirow{2}{*}{1.677} & \multirow{2}{*}{0.101} \\
\hline & & SFKM & 17 & 61.12 & 8.97 & & \\
\hline
\end{tabular}

Note. $* \mathrm{p}<0.05$.

Based on the employment status of the fathers, for the ones with fathers in working status, it is found out that the self-confidence scores at Internal Self-confidence and External Self-confidence sub dimensions of the individuals participating in sport activities are higher than of the individuals not participating in sport activities $(\mathrm{p}>0.05)$. No significant difference is seen for the ones with fathers in not working status $(p>0.05)$ (Table 5).

Table 6. According to the employment status of the mother, comparison of the Internal Self-confidence and External Self-confidence scores of the individuals participating in sport activities and the individuals not participating in sport activities

\begin{tabular}{|c|c|c|c|c|c|c|c|}
\hline & & & $\mathrm{n}$ & Ort. & S.S. & $\mathrm{t}$ & $\mathrm{p}$ \\
\hline \multirow{4}{*}{ Working } & \multirow{2}{*}{ Internal Self-confidence } & SFK & 39 & 67.72 & 9.85 & \multirow{2}{*}{0.971} & \multirow{2}{*}{0.335} \\
\hline & & SFKM & 37 & 65.22 & 12.52 & & \\
\hline & \multirow{2}{*}{ External Self-confidence } & SFK & 39 & 65.67 & 8.92 & \multirow{2}{*}{1.152} & \multirow{2}{*}{0.253} \\
\hline & & SFKM & 37 & 62.95 & 11.57 & & \\
\hline \multirow{4}{*}{ Not Working } & \multirow{2}{*}{ Internal Self-confidence } & SFK & 120 & 67.69 & 11.7 & \multirow{2}{*}{2.657} & \multirow{2}{*}{$0.009 *$} \\
\hline & & SFKM & 77 & 63.44 & 9.67 & & \\
\hline & \multirow{2}{*}{ External Self-confidence } & SFK & 120 & 64.56 & 10.87 & \multirow{2}{*}{3.057} & \multirow{2}{*}{$0.003 *$} \\
\hline & & SFKM & 77 & 59.77 & 10.53 & & \\
\hline
\end{tabular}

Note. $* \mathrm{p}<0.05$. 


\section{Mll Macrothink}

Based on the employment status of the mothers, when the Internal Self-confidence and External Self-confidence scores of the individuals participating in sport activities and of the individuals not participating in sport activities are examined, based on the employment status of the mothers, for the ones with mothers in not working status, it is found out that the self-confidence scores of the individuals participating in sport activities are significantly higher than of the individuals not participating in sport activities $(\mathrm{p}>0.05)$. No significant difference is seen for the ones with in working status $(p>0.05)$ (Table 6).

Table 7. According to the marital status of the parents, comparison of the Internal Self-confidence and External Self-confidence scores of the individuals participating in sport activities and the individuals not participating in sport activities

\begin{tabular}{|c|c|c|c|c|c|c|c|}
\hline & & & $n$ & Ort. & S.S. & $\mathrm{t}$ & $\mathrm{p}$ \\
\hline \multirow{4}{*}{ Married } & \multirow{2}{*}{ Internal Self-confidence } & SFK & 137 & 68.15 & 10.69 & \multirow{2}{*}{3.254} & \multirow{2}{*}{0.001 * } \\
\hline & & SFKM & 100 & 63.51 & 11.03 & & \\
\hline & \multirow{2}{*}{ External Self-confidence } & SFK & 137 & 65.18 & 10.13 & \multirow{2}{*}{3.611} & \multirow{2}{*}{$0.001 \%$} \\
\hline & & SFKM & 100 & 60.27 & 11.26 & & \\
\hline \multirow{4}{*}{ Divorced } & \multirow{2}{*}{ Internal Self-confidence } & SFK & 22 & 64.91 & 14.24 & \multirow{2}{*}{-0.67} & \multirow{2}{*}{0.507} \\
\hline & & SFKM & 13 & 67.64 & 6.69 & & \\
\hline & \multirow{2}{*}{ External Self-confidence } & SFK & 22 & 62.68 & 12.03 & \multirow{2}{*}{-0.527} & \multirow{2}{*}{0.602} \\
\hline & & SFKM & 13 & 64.57 & 7.36 & & \\
\hline
\end{tabular}

Note. ${ }^{*} \mathrm{p}<0.05$.

According to the marital status of the parents, for the ones with parents in married status, it is found out that the self-confidence scores at Internal Self-confidence and External Self-confidence sub dimensions of the individuals participating in sport activities are higher than of the individuals not participating in sport activities $(\mathrm{p}>0.05)$. For individuals with divorced parents, no significant difference is found based on the status of performing sport activities $(\mathrm{p}>0.05)$ (Table 7). 
Table 8. According to the number of siblings, comparison of the Internal Self-confidence and External Self-confidence scores of the individuals participating in sport activities and the Individuals not participating in sport activities

\begin{tabular}{|c|c|c|c|c|c|c|c|}
\hline & & & $\mathrm{N}$ & Ort. & S.S. & $\mathrm{t}$ & $\mathrm{p}$ \\
\hline \multirow{4}{*}{ 1-2 siblings } & \multirow{2}{*}{ Internal Self-confidence } & SFK & 76 & 68.34 & 11.97 & \multirow{2}{*}{2.099} & \multirow{2}{*}{0.038} \\
\hline & & SFKM & 60 & 64.2 & 10.7 & & \\
\hline & \multirow{2}{*}{ External Self-confidence } & SFK & 76 & 65.46 & 10.84 & \multirow{2}{*}{2.506} & \multirow{2}{*}{0.013} \\
\hline & & SFKM & 60 & 60.75 & 10.93 & & \\
\hline \multirow{4}{*}{3 ve fazla } & \multirow{2}{*}{ Internal Self-confidence } & SFK & 83 & 67.11 & 10.58 & \multirow{2}{*}{1.772} & \multirow{2}{*}{0.079} \\
\hline & & SFKM & 53 & 63.81 & 10.71 & & \\
\hline & \multirow{2}{*}{ External Self-confidence } & SFK & 83 & 64.25 & 10.02 & \multirow{2}{*}{1.866} & \multirow{2}{*}{0.064} \\
\hline & & SFKM & 53 & 60.85 & 11.02 & & \\
\hline
\end{tabular}

Note. $* \mathrm{p}<0.05$.

For the individuals with 1 or 2 siblings, the Internal Self-confidence score mean for the ones participating in sport activities is 68.34, and for the ones not participating in sport activities the same is 64.20. For the individuals with 1 or 2 siblings, the External Self-confidence score mean for the ones participating in sport activities is 65.46, and for the ones not participating in sport activities the same is 60.75 . For the individuals with 3 or more siblings, the Internal Self-confidence score mean for the ones participating in sport activities is 67.11 , and for the ones not participating in sport activities the same is 63.81 . For the individuals with 3 or more siblings, the External Self-confidence score mean for the ones participating in sport activities is 64.25 , and for the ones not participating in sport activities the same is 60.85 . For the individuals with 1 or 2 siblings, at Internal Self-confidence and External Self-confidence sub dimensions, it is found out that the self-confidence levels of the individuals participating in sport activities is higher compared to the individuals not participating in sport activities ( $\mathrm{p}<$ 0.05 ). For the individuals with 3 or more siblings, no significant differences are found based on the sport performance status $(\mathrm{p}>0.05)$ (Table 8$)$.

\section{Discussion}

It is seen that there is no significant difference as the result of comparison of the Internal Self-confidence and External Self-confidence scores of the individuals participating in sport activities based on the Father's Employment Status, Mother's Employment Status, marital status of the parents, number of siblings and the familial income status. Whereas at gender variable, while there is no significant difference at Internal Self-confidence sub dimension, at External Self-confidence sub dimension it is found out that males have significantly higher scores compared to females $(\mathrm{p}<0.05)$ (Table 2). The Internal and External Self-confidence 
scores of both females and males participating in sport activities are seen to be mutually significantly higher compared to the ones not participating (Table 4). Based on the employment status of the fathers, for the ones with fathers in working status, it is found out that the self-confidence scores at Internal Self-confidence and External Self-confidence sub dimensions of the individuals participating in sport activities are higher than of the individuals not participating in sport activities (Table 5). Whereas, based on the employment status of the mothers, when the Internal Self-confidence and External Self-confidence scores of the individuals participating in sport activities and of the individuals not participating in sport activities are examined, based on the employment status of the mothers, for the ones with mothers in not working status, it is found out that the self-confidence scores of the individuals participating in sport activities are significantly higher than of the individuals not participating in sport activities (Table 6). According to the marital status of the parents, for the ones with parents in married status, it is found out that the self-confidence scores at Internal Self-confidence and External Self-confidence sub dimensions of the individuals participating in sport activities are higher than of the individuals not participating in sport activities (Table 7). For the individuals with 1 or 2 siblings, at Internal Self-confidence and External Self-confidence sub dimensions, it is found out that the self-confidence levels of the individuals participating in sport activities is higher compared to the individuals not participating in sport activities (Table 8). According to the familial income status, the Internal Self-confidence and External Self-confidence scores are compared for the individuals participating in sport activities and the individuals not participating in sport activities. It is seen that for the group with income status as 2001-3000 TL, the individuals participating in sport activities has higher self-confidence scores than the individuals not participating in sport activities (Table 9) $(\mathrm{p}<0.05)$. It is known that there are several factors in formation of self-confidence and gender factor is only one of them. In the formation of the concept of self in an individual, gender roles have an important place. In the literature, there are some research, (Gümüş, 1997; Erkan et al., 2002) supporting the findings of this research regarding that the self-confidence levels show no difference between boys and girls. In addition Yildiz et al. (2016) indicated that gender difference has no effect on perception of self-confidence. Therefore, the findings of the study are parallel with the results of our study. When another study parallel to ours is examined, it is stated that gender difference has no significant effect on the self-confidence level (Özen et al., 2014). Soner (2000) states that whether mother working or not creates no significant difference for the academic success of the students. The same condition is also valid for the self-confidence of the students. Yildirım (2000) had studied the problems faced by the children with divorced parents before and after the divorce, it is determined that each of the variables loneliness, teachers, exam stress and "family" support are all separately affect the success. Furthermore, in the study of Y1lmaz (2011), the results are obtained that the self-confidence levels of the children growing in a distressful family environment are lower compared to the children of divorced couples. In addition, it is indicated that children of the divorced couples have lower self-confidence levels compared to the children in harmonic marriages. According to the findings of the study of Altunkaya (2010), when the in-family problems the individuals with divorced parents face in family, school and social environments and the opinions regarding these problems are examined, it is 
determined that there are decreases in the academic levels in courses, attending to school, being interested to the lessons for the students with divorced patents. Inci and Deniz (2015), according to the findings of their study, show that there is a decrease in the self-confidence level as the number of children increases in the family. Ersoy (2013), in his study, concluded that for the students perceiving the behavior of their parents as protective the number of siblings has an importance but for the children perceiving their families as democratic, it does not create a difference. In addition, according to the findings of the study of Bilgin (2011), the lowest self-confidence level score of the study was obtained at individuals with 5 and more siblings. In a family depending on the number of siblings, 5 and more, the individuals forming the family not showing sufficient interest at the children shall cause those individuals not to put themselves forward. In fact, our results are conforming to this opinion. Özyürek and Tezel Şahin (2005), in their study with parents, concluded that as the number of children increases, the fathers start to act farther away from democratic behavior, firmer and harsher against the children. Kasatura (1998) had concluded that the economic problems within the family shall cause the diminishing of the feeling of self-confidence in a student and instead lead to the development of feelings of fear and anxiety.

According to the research findings, as the result of the statistical analysis on comparison of the Internal Self-confidence and External Self-confidence scores of the individuals participated in the sport activities and the individuals not participated in the sport activities, it is concluded that there is a significant difference at the External Self-confidence sub dimension (Table 3). According to Zorba (2012), the regular sport activities has determined to have a contribution to increase in self-respect and self-confidence at individuals. Also, it is emphasized that it creates positive results for the individuals. In the study of Bostanc1 et al. (2016), the self-confidence levels of the university students at sports schools present similarities with the findings of our study. On the other hand in findings of the study (Can \& Kaçay 2016), it is seen that there is an increase in self-confidence in people who had been performed and are performing sport activities. Özbek et al. (2017), in the study, conducted on the comparison of the self-confidence levels of the sportive and sedentary high school students, concluded that the sedentary students have lower Internal and External Self-confidence levels compared to the students active in sports. In addition, according to the findings of the study of Gürer (2017), it is concluded that self-confidence is affective on the performance. Şahin (2015), in his study, related to the self-confidence levels of athletes and sedentary individuals, concluded that there is an average level positive relationship as the result of the self-confidence scores of the individuals active in sports. Also Tiryaki (2000), as the result of his study, concluded that self-confidence is connected with the formation of personality, and by indicating that there is a significant difference between the athletes and non-athletes, concluded that athletes are more lively, hardworking and open to communication. As the result of this study, the goal is the better understanding the self-confidence levels of the individuals at the ages 13-14 participating in sport activities at Youth Centers and the determination of its difference compared to individuals not participating in sport activities; and in turn these processes can be comprehensively analyzed in the country including the regions. As the self-confidence levels of sedentary individuals are lower due to them not participating in sport activities, they should be directed to youth 
centers or clubs including sportive activities, they should be encouraged to go there. The contents and at the same time applicability of the established plans of the activities to be applied can be researched and supported in a comprehensive study to be conducted together with the Youth Centers.

\section{References}

Akın, A. (2007). Özgüven ölçeğinin geliştirilmesi ve psikometrik özellikleri. Abant İzzet Baysal Üniversitesi Ĕ̌itim Fakültesi Dergisi, 7(2), 165-170.

Altunkaya, E. (2010). Anne Babası Boşanmış Ilköğretim Öğrencilerinin Okul-Aile ve Sosyal Ortamlarda Yaşadıkları Problemlere Ilişkin Görüşleri (Abant İzzet Baysal Üniversitesi Sosyal Bilimler Enstitüsü, Bolu).

Başoğlu, S. T. (2007). Sınav Kaygısı ile Özgüven Arasındaki Ilişkinin Erinlik Döneminde Incelenmesi (Maltepe Üniversitesi Sosyal Bilimler Enstitüsü, İstanbul).

Bilgin, O. (2011). Ergenlerde Özgüven Düzeyinin Bazı Değişkenler Açısından Incelenmesi (Sakarya Üniversitesi Sosyal Bilimler Enstitüsü, Sakarya).

Bostanc1, T. G., Özen, G., Yıldı, N. O., \& Üzüm, H. (2016). Studyıng self-confidence perception of school of education and sports students in terms of different variables. The 10th International Conference in Physical Education, Sports and Physical Therapy November $18-20,2016$.

Burton, K., \& Platts, B. (2010). Building Self-Confidence for Dummies. Chichester, West Sussex: John Wiley and Sons.

Can, Y., \& Kaçay, Z. (2016). Sporcu kimlik algısı ile cesaret ve özgüven duyguları arasındaki ilişkilerin incelenmesi. Journal of Human Sciences, 13(3), 6176-6184. https://doi.org/ 10.14687/jhs.v13i3.4353

Ceylan, T., Ermiş, E., Ceylan, L., \& Erilli, N. A. (2020). Futbol hakemlerinin sargınlık ve öz yeterlik düzeylerinin incelenmesi. Journal of International Social Research, 13(75), 934-940. https://doi.org/10.17719/jisr.11161

Erkan, Z., Güçray, S. V., \& Çam, S. (2002). Ergenlerin sosyal kaygı düzeylerinin ana baba tutumları ve Gender açısından incelenmesi. Çukurova Üniversitesi Sosyal Bilimler Enstitüsü Dergisi, 10(10), 64-75.

Ersoy, E. (2013). Ortaokul Çocuklarının Algıladıkları Anne Baba Tutumları ile Benlik Saygısı ve Depresyon Düzeyi Arasındaki Ilişkinin Incelenmesi (İstanbul İli Fatih İlçesi Örneği) (Fatih Üniversitesi Sosyal Bilimler Enstitüsü, İstanbul).

Gökhan, N., Olgun, P., \& Gürses, Ç. (1979). Sportif Yetenek Araştırma Metodu Türkiye Uygulaması. İstanbul: TSV.

Gümüş, A. (1997). Üniversite Öğrencilerinin Sosyal Kaygı Düzeylerinin Çeşitli Değişkenlere Göre Incelenmesi (Gazi Üniversitesi Sosyal Bilimler Enstitüsü, Ankara). 


\section{Macrothink

Gürer, B. (2017). The research about reasons of mountaineers' attend to 1ce climbing and its effects on their self-confidence. European Journal of Education Studies, 3(8), 501-515.

Humphreys, T. (2002). Çocuk Ĕ̆itiminin Anahtarı: Özgüven. İstanbul: Epsilon Yayınları.

İnci, M. A., \& Deniz, Ü. (2015). Baba tutumları ile çocuğun yaşı, cinsiyeti, doğum sırası ve kardeş sayısı değişkenleri arasındaki ilişkinin incelenmesi. Karadeniz Sosyal Bilimler Dergisi, $7(2), 1-9$.

Kasatura, İ. (1998). Kişilik ve Özgüven. İstanbul: Evrim Yayınevi.

Kurtuldu, P. S. (2007). Illköğretim Okulu Yöneticilerinin Özgüven Düzeyleri ile Liderlik Düzeyleri Arasındaki Ilişkinin Incelenmesi (Yeditepe Üniversitesi Sosyal Bilimler Enstitüsü, İstanbul).

Mahoney, M. J., \& Chapman, B. P. (2004). Psychological Skills Training in Sport. Texas: University of North Texas. https://doi.org/10.1016/B0-12-657410-3/00811-4

Özbek, S., Yoncalık, M. T., \& Alıncak, F. (2016). Sporcu ve sedanter lise öğrencilerinin özgüven düzeylerinin karşılaştırılması (Kırşehir İli Örneği). Gaziantep Üniversitesi Spor Bilimleri Dergisi, 2(3), 46-56.

Özen, G., Özen, Ş., \& Sönmez, G. T. S. (2014). Kamp yaşantısı ve engel aktivitelerin katılımcıların öz-etkililik algılarına etkisi. Spor ve Performans Araştırmaları Dergisi, 5(2), 5-12. https://doi.org/10.17155/spd.78927

Özyürek, A., \& Tezel Şahin, F. (2005). 5-6 yaş grubunda çocuğu olan ebeveynlerin tutumlarının incelenmesi. Gazi Eğitim Fakültesi Dergisi, 25(2), 19-34.

Şahin, M. K. (2015) Okul Öncesi Öğretmenlerinin Öz Güvenleri ve Meslek Tutumlarının Incelenmesi (Afyon Kocatepe Üniversitesi Sosyal Bilimler Enstitüsü, Afyon).

Soner, O. (2000). Aile uyumu, öğrenci özgüveni ve akademik başarı arasındaki ilişkiler. Marmara Üniversitesi Atatürk Ĕ̈itim Fakültesi Eğitim Bilimleri Dergisi, 12(12), 249-260.

Tiryaki, Ş. (2000). Spor psikolojisi. İstanbul: Eylül Kitap ve Yayınevi.

Vealey, R. S. (2009). Confidence in Sport: Handbook of Sports Medicine and Science Sport Psychology. Miami University: OH Publishers.

Weinberg, R., \& Gould, D. (2003). Psychological Foundations in Sport and Exercise. Illinois: Human Kinetics Press.

Yıldırım, İ. (2000). Akademik başarının yordayıcısı olarak yalnızlık, sınav kaygısı ve sosyal destek. Hacettepe Üniversitesi Eğitim Fakültesi Dergisi, 18(1), 167-176.

Yılmaz, N. D. (2011). Çatışma Yaşayan Ve Boşanmış Ailelerin Ilköğretim Çağındaki 7-12 Yaş Çocuklarının Benlik Algları ve Kaygı Düzeyleri Açısından Çatışma Yaşamayan Ailelerin Çocukları ile Karşılaştırılması (Maltepe Üniversitesi Sosyal Bilimler Enstitüsü, İstanbul).

Zorba, E. (2012). Herkes Için Yaşam Boyu Spor. Ankara: Neyir Yayınları. 


\section{Copyright Disclaimer}

Copyright for this article is retained by the author(s), with first publication rights granted to the journal.

This is an open-access article distributed under the terms and conditions of the Creative Commons Attribution license (http://creativecommons.org/licenses/by/3.0/). 